\title{
Dietetic requirements and evaluation of a small ruminant nutrition system model in Morada Nova lambs
}

\section{Requerimentos dietéticos e avaliação do modelo small ruminant nutrition system em cordeiros Morada Nova}

\author{
Marcus Roberto Goes Ferreira Costa ${ }^{1}$; Elzânia Sales Pereira ${ }^{2}$; Ariosvaldo Nunes \\ de Medeiros ${ }^{3}$; Andréa Pereira Pinto ${ }^{4 *}$; Ronaldo Lopes Oliveira ${ }^{5}$; Ivone Yurika \\ Mizubuti ${ }^{6}$; Edson Luis de Azambuja Ribeiro ${ }^{6}$; Maria Socorro de Souza Carneiro ${ }^{4}$; \\ Ana Claudia Nascimento Campos ${ }^{4}$; Patrícia Guimarães Pimentel ${ }^{4}$
}

\begin{abstract}
This study was carried out to estimate efficiencies of the utilization of metabolizable energy for maintenance $(\mathrm{km})$ and weight gain $(\mathrm{kg})$ and to evaluate the Small Ruminant Nutrition System (SRNS) model in predicting dry matter intake (DMI) and average daily gain (ADG) of growing Morada Nova lambs. The animals were non-castrated and two months of age, with initial body weights averaging 12.05 $\pm 1.81 \mathrm{~kg}$. Eight animals were slaughtered at the beginning of the trial as a reference group, in order to estimate initial empty body weight and body composition. The remaining animals were assigned to a randomized block design with eight replications per block and five diets with increasing metabolizable energy levels $(0.96,1.28,1.72,2.18$ and $2.62 \mathrm{Mcal} / \mathrm{kg}$ of dry matter (DM)). The metabolizable energy use efficiencies for maintenance and for weight gain were calculated from the relationship between the dietary net energy for maintenance and gain and ME concentration in the diets. Evaluation of the SRNS model was performed by adjustment of simple linear regression model between the predicted (independent variable) and observed (dependent variable) values. The efficiency of ME utilization for maintenance $(0.96 \mathrm{Mcal} / \mathrm{kg} \mathrm{DM})$ was 0.24 and decreased $(0.60$ to 0.40$)$ for the other treatments with increasing energy content. The DMI and ADG predicted by the SRNS model did not differ $(\mathrm{P} \leq 0.05)$ from the observed values. Thus, the SRNS model can be used to estimate the DMI and ADG in feedlot Morada Nova lambs.
\end{abstract}

Key words: Crude protein, metabolizability, nutritional requirement

\section{Resumo}

O estudo foi conduzido para estimar as eficiências de utilização da energia metabolizável (EM) para mantença $(\mathrm{km})$ e ganho de peso $(\mathrm{kg})$ e avaliação do modelo Small Ruminant Nutrition System (SRNS) para predição do consumo de matéria seca (CMS) e ganho médio diário (GMD) de cordeiros Morada Nova em crescimento. Os animais não castrados e com dois meses de idade, apresentaram peso corporal

1 Prof. Dr., Instituto Federal de Educação, Ciência e Tecnologia do Ceará, CE, Brasil. E-mail: mr.goes@gmail.com

Prof ${ }^{\mathrm{a}}$. Dr ${ }^{\mathrm{a}}$, Dept ${ }^{\mathrm{o}}$ de Zootecnia, UFC, Fortaleza, CE, Brasil. Bolsista de Produtividade do CNPq. E-mail: elzania@hotmail.com

Prof. Dr., Dept ${ }^{\circ}$ de Zootecnia, Universidade Federal da Paraíba, UFPB, PB, Brasil. E-mail: ariosvaldo.medeiros@gmail.com

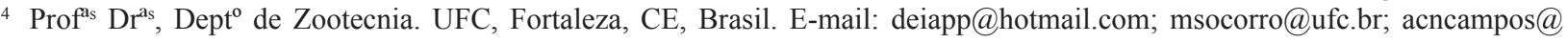
gmail.com; pgpimentel@hotmail.com

5 Prof. Dr., Dept ${ }^{\circ}$ de Zootecnia, Universidade Federal da Bahia, UFBA, Salvador, BA, Brasil. E-mail: ronaldozootecnista@ hotmail.com

6 Profs. Drs., Dept ${ }^{\mathrm{o}}$ de Zootecnia, Universidade Estadual de Londrina, UEL, Londrina, PR, Brasil. E-mail: mizubuti@uel.br; elar@uel.br

* Author for correspondence 
médio inicial de $12,05 \pm 1,81 \mathrm{~kg}$. Oito animais foram abatidos no início do experimento como grupo referência, com o objetivo de estimar o peso do corpo vazio inicial e a composição corporal. Os animais remanescentes foram distribuídos em delineamento em blocos inteiramente casualizados com oito repetições por bloco e cinco dietas com níveis crescentes de energia metabolizável $(0,96,1,28$, $1,72,2,18$ e $2.62 \mathrm{Mcal} / \mathrm{kg}$ de matéria seca (MS)). As eficiências de uso da energia metabolizável para mantença e ganho de peso foram calculados a partir da relação entre a energia líquida dietética para mantença e ganho e a concentração de EM nas dietas. A avaliação do modelo SRNS foi realizada por meio do ajuste do modelo linear de regressão simples entre os valores preditos (variável independente) e observados (variável dependente). A eficiência de utilização da EM para mantença ( $0,96 \mathrm{Mcal} / \mathrm{kg} \mathrm{MS})$ foi 0,24 e diminuiu $(0,60$ para 0,40$)$ para os demais tratamentos com o aumento do nível de energia. $\mathrm{O}$ CMS e o GMD preditos pelo modelo SRNS não diferiram $(\mathrm{P} \leq 0,05)$ dos valores observados. Assim, o modelo SRNS pode ser utilizado para estimar o CMS e o GMD de rebanhos de cordeiros Morada Nova. Palavras-chave: Metabolizabilidade, proteína bruta, requerimento nutricional

\section{Introduction}

The feeding systems for small ruminants are largely based on tables and empirical equations developed using production conditions established by or similar for the country from which the data originated (CSIRO, 1990, NRC, 2000; 2007, FOX et al., 2004, CANNAS et al., 2004; 2007).

Based on the efficiency of utilization of metabolizable energy $(\mathrm{k})$, the required metabolizable energy (ME) and total digestible nutrients (TDN) can be calculated. The efficiency of utilizing metabolizable energy for small ruminants varies widely due to the different methodologies used to evaluate the feed and nutritional requirements. The AFRC (1993) and INRA (1978) estimate efficiencies from equations that use the metabolizability (qm) of the diets as independent variables, where qm is the relationship between the dry matter (DM) and gross energy (GE) of the diets.

The NRC (2007) and CNCPS-Sheep (CANNAS et al., 2004) obtain the efficiency of utilizing metabolizable energy from cubic equations proposed by Garrett (1980). Sheep studies in Brazil have used the equations described in the AFRC (1993) to estimate the efficiency of utilizing metabolizable energy, but some researchers have determined efficiencies from experimental data itself using the interactive process to estimate the $\mathrm{km}$ or slope of the straight line of the plot of metabolizable energy intake against the energy retained in the animal body.
Mechanistic models for feed and nutritional requirement assessment have been developed over the past 20 years to compile the knowledge developed in the area of nutrition and to identify the knowledge gaps in this area. Several models predict animal responses to feed (REGADAS FILHO et al., 2011), climate and animal inputs. Among them, the model Cornell Net Carbohydrate and Protein System - Sheep (CNCPS-S) (CANNAS et al., 2004) and, more recently, the Small Ruminant Nutrition System (SRNS) (TEDESCHI; FOX; RUSSELL, 2000) are the most prominent. The latter is a modification of the CNCPS-S that includes the most recent information, in addition to a sub-model of goat nutrition.

The use of mechanistic models to measure food and nutritional requirements of ruminants (CANNAS et al., 2004; 2007) has been developed to more thoroughly evaluate complete diets to minimize nutrient losses and environmental impact and to maximize the food utilization efficiency of the animals. Therefore, the accuracy of such estimates for specific breeds used in semiarid regions must be thoroughly assessed (REGADAS FILHO et al., 2011).

Thus, the objectives of this study were to estimate the efficiencies of the utilization of metabolizable energy for maintenance and weight gain and to evaluate the Small Ruminant Nutrition System (SRNS) model in predicting dry matter intake and average daily gain of growing Morada Nova lambs. 


\section{Material and Methods}

\section{Experimental site}

This trial was conducted at the Department of Animal Science, Federal University of Ceara, in Fortaleza, state of Ceara (CE), Brazil, from February to June, 2010. Humane animal care and handling procedures were followed according to the animal care committee (CEUA, Comissão de Ética no Uso de Animais da Universidade Estadual de Londrina, PR).

\section{Development database}

The 48 Morada Nova lambs used were noncastrated males, about 2 months of age, with an average initial body weight $(\mathrm{BW})$ of $12.05 \pm 1.81$ $\mathrm{kg}$. The animals were identified, dewormed and placed in individual stalls with feeding troughs that supplied the diets and water ad libitum. After a ten day adaptation period, eight animals were randomly selected and slaughtered as a reference for the empty body weight (EBW) estimates and initial body composition. The remaining lambs (n $=40$ ) were randomly allocated into five treatments (8 animals/treatment) that consisted of increasing levels of metabolizable energy $(0.96,1.28,1.72$, 2.18 and $2.62 \mathrm{Mcal} / \mathrm{kg} \mathrm{DM}$ ).

The experimental diets were formulated according to the NRC (2007). The animals were fed diets as total mixed rations (TMR) twice daily (at 8 a.m. and 4 p.m.) ad libitum, which allowed for up to $10 \%$ orts. Before morning supply, the diet orts of each animal were removed and weighed as a daily control. The daily dry matter intake (DMI) was calculated as the difference between the weight of the diet offered and the orts. The diets were composed of Tifton 85 hay (as roughage) and concentrates based on corn grain, soybean meal, urea, limestone, dicalcium phosphate, sodium chloride and a mineral premix (Table 1 and 2).

Table 1. Chemical composition of ingredients and concentrates $(\mathrm{g} / \mathrm{kg} \mathrm{DM})$.

\begin{tabular}{lcccccccc}
\hline Nutrient & Corn meal & $\begin{array}{c}\text { Soybean } \\
\text { meal }\end{array}$ & $\begin{array}{c}\text { Tifton } 85 \\
\text { hay }\end{array}$ & Conc. 1 & Conc. 2 & Conc.3 & Conc.4 & Conc.5 \\
\hline DM & 891.0 & 951.8 & 953.6 & 967.0 & 962.4 & 954.3 & 958.3 & 947.3 \\
OM & 879.3 & 885.7 & 873.8 & 930.4 & 889.2 & 911.9 & 919.5 & 903.2 \\
CP & 91.4 & 546.3 & 78.9 & 298.6 & 525.5 & 279.3 & 221.3 & 188.9 \\
EE & 53.9 & 29.1 & 14.6 & 25.4 & 29.7 & 36.7 & 34.2 & 30.8 \\
Ash & 11.7 & 66.1 & 79.8 & 36.6 & 73.2 & 42.4 & 38.8 & 44.1 \\
NDF & 176.6 & 154.3 & 754.0 & 128.7 & 132.0 & 142.9 & 140.6 & 145.8 \\
ADF & 82.8 & 145.4 & 447.2 & 96.7 & 75.2 & 44.0 & 48.6 & 47.2 \\
Lignin & 8.1 & 37.3 & 51.2 & 9.5 & 13.8 & 16.4 & 18.9 & 19.4 \\
Cellulose & 24.1 & 55.3 & 304.4 & 35.7 & 72.0 & 33.7 & 33.5 & 35.3 \\
Hemicel. & 93.8 & 8.9 & 306.8 & 32.0 & 56.8 & 98.9 & 92.0 & 98.6 \\
TC & 842.9 & 358.4 & 826.7 & 675.1 & 393.6 & 662.0 & 680.6 & 693.7 \\
FC & 138.8 & 104.2 & 701.3 & 96.0 & 99.5 & 110.7 & 95.3 & 104.0 \\
NFC & 704.1 & 254.2 & 125.3 & 579.1 & 294.1 & 551.3 & 585.3 & 589.7 \\
\hline
\end{tabular}

$\mathrm{DM}=$ Dry matter; $\mathrm{OM}=$ Organic matter; $\mathrm{CP}=$ Crude protein; $\mathrm{EE}=$ Ether extract; $\mathrm{NDF}=$ Neutral detergent fiber; ADF = Acid detergent fiber; $\mathrm{TC}=$ Total carbohydrate; $\mathrm{FC}=$ Fibrous carbohydrates; $\mathrm{NFC}=$ Non-fibrous carbohydrates; Conc. $=$ Concentrate. Source: Elaboration of the authors. 
Digestibility trials were conducted eight times throughout the experiment to determine the ME of the diet. Indigestible neutral detergent fiber (iNDF) was used as a marker to estimate fecal dry matter excretion, as described by Casali et al. (2008). Feces were collected for three consecutive days every 15 days during the experimental period, at 8 a.m. on the first day, at noon on the second day and at 4 p.m. on the third day.

Table 2. Percentage and chemical composition of experimental diets.

\begin{tabular}{|c|c|c|c|c|c|}
\hline \multirow{2}{*}{ Ingredient (\%) } & \multicolumn{5}{|c|}{ Levels of ME (Mcal/kg DM) } \\
\hline & 0.96 & 1.28 & 1.72 & 2.18 & 2.62 \\
\hline Tifton hay & 95 & 80 & 60 & 40 & 20 \\
\hline Concentrate & 5 & 20 & 40 & 60 & 80 \\
\hline Corn meal $^{1}$ & 62.63 & 15.87 & 69.45 & 72.46 & 75.61 \\
\hline Soybean meal $^{1}$ & 32.62 & 80.65 & 28.53 & 24.88 & 22.59 \\
\hline Urea $^{1}$ & 3.77 & 3.00 & 1.25 & 1.12 & 0.51 \\
\hline Limestone $^{1}$ & - & - & - & 0.54 & 0.66 \\
\hline Dicalcium phosphate $^{1}$ & - & - & - & - & 0.07 \\
\hline Sodium chloride ${ }^{1}$ & 0.86 & 0.4 & 0.7 & 0.93 & 0.50 \\
\hline \multirow[t]{2}{*}{ Mineral premix ${ }^{1,2}$} & 0.12 & 0.08 & 0.07 & 0.07 & 0.06 \\
\hline & \multicolumn{5}{|c|}{ Chemical composition (g/kg DM) } \\
\hline Dry matter & 954.3 & 955.4 & 953.9 & 956.4 & 951.2 \\
\hline Ash & 38.0 & 78.5 & 64.8 & 55.2 & 51.2 \\
\hline Crude protein & 89.9 & 168.2 & 159.1 & 164.4 & 166.9 \\
\hline Ether extract & 24.9 & 26.7 & 27.9 & 22.4 & 27.6 \\
\hline Neutral detergent fiber & 722.5 & 629.6 & 509.6 & 386.0 & 267.4 \\
\hline Acid detergent fiber & 429.6 & 372.8 & 285.9 & 208.0 & 127.2 \\
\hline Lignin & 49.1 & 43.7 & 37.3 & 31.8 & 25.8 \\
\hline Cellulose & 293.2 & 259.8 & 197.6 & 142.8 & 89.6 \\
\hline Hemicellulose & 293.0 & 256.8 & 223.7 & 178.0 & 140.2 \\
\hline NDFap $^{3}$ & 671.1 & 581.0 & 465.1 & 337.7 & 223.5 \\
\hline Total carbohydrate & 817.3 & 735.7 & 764.6 & 754.0 & 746.3 \\
\hline Non-fibrous carbohydrates & 146.2 & 154.7 & 299.5 & 416.3 & 522.8 \\
\hline Total digestible nutrients & 280.1 & 344.6 & 453.9 & 593.9 & 723.6 \\
\hline $\mathrm{TDN}: \mathrm{CP}^{4}$ & 3.12 & 2.04 & 2.85 & 3.61 & 4.33 \\
\hline
\end{tabular}

${ }^{1}$ Centesimal concentration in relation to the concentrated portion of the diets; ${ }^{2} \mathrm{Composition}: \mathrm{Ca}-7.5 \% ; \mathrm{P}-3 \% ; \mathrm{Fe}-16.500$ ppm; $\mathrm{Mn}-9.750 \mathrm{ppm} ; \mathrm{Zn}-35.000 \mathrm{ppm}$; I $1.000 \mathrm{ppm}$; Se - $225 \mathrm{ppm}$; Co $-1.000 \mathrm{ppm} ;{ }^{3}$ Neutral detergent fiber corrected for ash and protein; ${ }^{4}$ Total digestible nutrients:Crude protein.

Source: Elaboration of the authors.

The iNDF amount in the fecal samples, orts, concentrates and Tifton 85 hay were obtained through waste in situ incubations of 240 hours in the rumen of a cow receiving a diet of Tifton 85 hay and concentrates based on corn grain, soybean meal, urea, limestone, dicalcium phosphate, sodium chloride and a mineral premix. The roughage:concentrate ratio was 60:40. Incubations were performed in nylon bags with $50 \mu \mathrm{m}$ pores and a ratio of $15 \mathrm{mg}$ per $\mathrm{cm}^{2}$ of sample bag. The protocols used were as according to the methodology described by McDonald and Orskov (1979). After this period, the bags with the incubation residues were washed in water until they were completely clear. Subsequently, they were boiled for 1 hour in a neutral detergent solution (VAN SOEST; ROBERTSON, 1985), and the remains were weighed and recorded as the iNDF (CASALI et al., 2008). 
The forage, concentrate, TMR and refuse samples were dried in a forced air oven at $55^{\circ} \mathrm{C}$ for 72 hours and then ground in a knife mill with a $1 \mathrm{~mm}$ screen (Wiley mill, Arthur H. Thomas, Philadelphia, PA, USA). The samples were analyzed for the following contents: dry matter (DM) (AOAC, 1990); method number 930.15, ash (AOAC, 1990); method number 924.05, crude protein (CP) (AOAC, 1990); method number 984.13, ether extract (EE) (AOAC, 1990); method number 920.39, acid detergent fiber (ADF) (AOAC, 1990); method number 973.18, neutral detergent fiber (VAN SOEST; ROBERTSON; LEWIS, 1991) and fibrous carbohydrates (FC) (SNIFFEN et al., 1992).

To analyze the neutral detergent fiber (NDF), the samples were treated with thermo-stable alpha amylase without sodium sulfite and were corrected for residual ash (MERTENS, 2002) and nitrogenous compounds (LICITRA; HERNANDES; VAN SOEST, 1996). The total carbohydrate content (TC) was calculated using the following equation: TC $(\%)=100-(\% \mathrm{CP}+\% \mathrm{EE}+\%$ ash $)(\mathrm{SNIFFEN} \mathrm{et}$ al., 1992). The non-fibrous carbohydrates (NFC) were calculated from the equation adapted from Weiss (1999), where NFC $(\%)=100-(\%$ NDFpa + $\% \mathrm{CP}+\% \mathrm{EE}+\%$ ash). For the concentrates, due to the presence of urea in their constitution, the NFC was calculated from the adapted equation by Hall (2000), where NFC $=100-[(\% \mathrm{CP}-\% \mathrm{CP}$ derived from urea $+\%$ of the urea) $+\% \mathrm{NDFpa}+\% \mathrm{EE}+$ \%ash].

\section{Performance and slaughter procedures}

The animals were weighed weekly to calculate the average daily gain (ADG). When the BW mean for a particular dietary treatment reached $25 \mathrm{~kg}$, the animals were slaughtered. One animal from the group with the lowest dietary energy concentration (0.96 Mcal $/ \mathrm{kg}$ DM of ME) was also slaughtered at this time. This procedure was performed for each group until all of the animals were slaughtered.
Before slaughter, the shrunk body weight (SBW) was measured as the BW after 18 hours of food and water fasting. At slaughter, the lambs were stunned using a cash knocker and killed by exsanguination from the jugular vein using conventional procedures.

The blood was weighed and sampled. The gastrointestinal tract was weighed full, then emptied, washed out and, after draining, weighed again, together with the organs and other body parts (carcass, head, skin, blood, full paw and tail). The body was separated into individual components, which were weighed separately, including the internal organs (liver, heart, bladder, kidneys, reproductive tract and spleen, and combinations of lung + trachea and tongue + esophagus), the cleaned digestive tract (rumen, reticulum, omasum, abomasum, and the small and large intestines) and fats (omental, perirenal, mesenteric and heart fats). The empty body weight (EBW) was calculated as the SBW at slaughter minus the digestive tract contents. All carcasses were weighed hot (approximately 1 hour after collection) and then cooled $\left(-4^{\circ} \mathrm{C}\right)$ for approximately 24 hours. The chilled carcasses were weighed again and then longitudinally halved with a band saw.

The organs, full paw, head and the right half of the carcass were ground separately in an industrial meat grinder. The combined mass of the ground organs, blood, full paw, head and right half of the carcass and skin were homogenized, sampled and placed in a forced ventilation oven at $55^{\circ} \mathrm{C}$ for 72 hours. After this procedure, the samples were defatted by extraction with ether in a soxhlet apparatus (AOAC, 1990); method number 920.39. After extraction, the samples were ground in a ball mill and stored in closed containers. The dry matter contents were determined by placing samples in an oven at $105^{\circ} \mathrm{C}$ until a constant weight was reached. The ash and crude protein levels were determined on fat-free samples following the method described above for experimental diet ingredients. 
Determination of the efficiency of the utilization of metabolizable energy and dietetic requirements

The dietary digestible energy (DE) was estimated to be $4.409 \mathrm{Mcal} / \mathrm{kg}$ of TDN (total digestible nutrients, according to WEISS, 1999), and the DE was converted to metabolizable energy (ME) using an efficiency of $82 \%$ (NRC, 2000). The metabolizability (qm) was calculated as: $\mathrm{qm}=\mathrm{ME} /$ GE for each experimental diet (AFRC, 1993).

The net requirement of energy and protein for maintenance and gain was obtained from Costa et al. (2013), where the nonlinear form of the model employed by Lofgreen and Garrett (1968) was used to describe the heat production at zero intake of metabolizable energy. The $\mathrm{km}$ was estimated from the interactive method, in which the balance between heat production and metabolizable energy intake was obtained.

The dietary net energy concentrations were calculated according to Harris (1970). The dry matter intake to maintain energy balance was calculated by dividing the metabolizable energy requirement for maintenance (MEm) by the concentration of the dietary ME, where MEm represents the relationship between the net energy for maintenance (NEm) divided by the metabolizability found by the interactive method. The net energy concentration of each diet for maintenance (NEmd) was obtained by dividing the heat production in fasting animals $\left(52.36 \mathrm{kcal} / \mathrm{kg}^{0.75} \mathrm{EBW} /\right.$ day) by the DMI to maintain the energy balance expressed in $\mathrm{g} \mathrm{DM} / \mathrm{kg}^{0.75} \mathrm{EBW} /$ day. The DMI over the maintenance need was obtained by subtracting the DMI sufficient for energy balance (g DM/ $\left.\mathrm{kg}^{0.75} \mathrm{EBW}\right)$ for each diet from the total DMI (g DM/ $\mathrm{kg}^{0.75} \mathrm{EBW}$ ). The net energy concentration for weight gain (NEgd) was calculated by dividing the energy retained per day ( $\mathrm{kcal} / \mathrm{kg}^{0.75} \mathrm{EBW}$ ) by the DMI (above maintenance requirement), expressed as $\mathrm{g} \mathrm{DM} / \mathrm{kg}^{0.75} \mathrm{EBW}$.

The efficiency of the utilization of metabolizable energy for maintaining and gaining weight was also estimated from the equations recommended by the AFRC (1993):

$$
\begin{aligned}
& \mathrm{km}=0.503+0.35 \times \mathrm{qm} \\
& \mathrm{kg}=0.006+0.78 \times \mathrm{qm}
\end{aligned}
$$

To express the metabolizable protein requirements, efficiencies of metabolizable protein for maintenance $(\mathrm{kpm})$ and weight gain $(\mathrm{kpg})$ equal to 1 and 0.59 , respectively, were used (AFRC, 1993). To convert the metabolizable protein requirement into crude protein, we used the equations proposed by the NRC (1996) for beef cattle due to the lack of sheep data.

To convert the net requirements into the EBW for net requirements in $\mathrm{BW}$, linear regression equations were adjusted between the daily EBW weight gain and the daily BW weight gain of all experimental animals. For the linear regression equation between the EBW and BW, experimental and reference animals were used.

A multiple DMI equation was generated in relation to daily weight gain and metabolic weight. We adopted data for the mean weekly DMI, metabolic BW and BW gain, which allowed us to obtain several measurements per animal during the experimental trial with different metabolic weights and weight gains.

\section{Statistical evaluation}

The most important characteristic of a model is accuracy (TEDESCHI; FOX; RUSSELL, 2000). Biological models should be compared with observed data to assess robustness, accuracy, and precision (KOHN; KALSCHEUR; HANIGAN, 1998). Such empirical validations should also include a suitable statistical evaluation (MITCHELL; SHEEHY, 1997).

The SRNS model was evaluated for its applicability to hair sheep through the Pearson's coefficient correlation (r) and by adjusting the linear regression equation between the predicted (independent variable) and observed (dependent variable) values. The equation parameters were tested together on the following hypothesis using the $\mathrm{F}$ test: 


$$
\begin{gathered}
H_{0}: \beta_{0}=0, \beta_{1}=1 \\
H_{A}: \operatorname{not} H_{0}
\end{gathered}
$$

The null hypothesis was rejected if the predicted and observed values were similar; otherwise, the tendency of the model to underestimate or overestimate the DMI or average daily gain (ADG) was calculated by dividing the mean of the Y-variate minus the mean of the $\mathrm{X}$-variate by the mean of the X-variate (TEDESCHI; FOX; RUSSEL, 2000). To measure the differences between the values predicted by the model or an estimator and the observed values, we used the root-mean-square error (RMSE).

The experimental design was a randomized block (stall type) with five treatments based on the following mathematical model: Yij $=\mu+\alpha i$ $+\beta \mathrm{j}+\mathrm{eij}$, where Yij $=$ value observed in the plot that received treatment $\mathrm{i}$ in block $\mathrm{j}, \mu=$ general average of the population, $\alpha \mathrm{i}=$ effect of treatment $\mathrm{i}, \beta \mathrm{j}=$ effect of the block, and eij = random error. The initial weights of the animals were used as a covariate. Statistical analyses were performed using PROC GLM of the SAS version 9.0 (SAS, 2003). An orthogonal partition of the sum of the square of the treatments into linear or quadratic degree effects was obtained following the analysis of variance. When the significance level of 0.05 was observed, we adjusted the regression equation using PROC REG SAS (9.0).

\section{Results and Discussion}

The nonlinear form of the model employed by Lofgreen and Garrett (1968) was used to describe the heat production at zero metabolizable energy intake. According to the exponential equation between the heat production (HP) and metabolizable energy intake (MEI) (Figure 1), the net requirement of energy for maintenance was $52.36 \mathrm{kcal} / \mathrm{kg}^{0.75}$ $\mathrm{EBW} /$ day. Considering the equation $\mathrm{HP}=52.36$ (3.42) $\exp ^{(0.005(0.0004) * \mathrm{MEI})}$, and using the interactive method, the value that yielded a heat production equal to an MEI of $81.00 \mathrm{kcal} / \mathrm{kg}^{0.75} \mathrm{EBW} /$ day was also equal to the metabolizable energy requirement for maintenance.

The low value observed for the dietary TDN with $0.96 \mathrm{Mcal} / \mathrm{g} \mathrm{DM}$ can be explained by the poor quality of the Tifton 85 hay (Table 3). According to Cappelle et al. (2001), tropical grasses are inversely proportional to the content and TDN values of the NDF and ADF. High values of these components in the forage, presented in Table 1, depreciated the TDN value.

According to Valadares Filho (1985), the forage energy values are overestimated because most TDN values in the literature were obtained with animals fed at a maintenance level. The author suggest that the TDN content should be reduced by $4 \%$ for each increase in intake above maintenance, so a need for reassessing the TDN contents of forage used in Brazil. 
Figure 1. Exponential relationship between heat production (HP) and metabolizable energy intake (MEI).

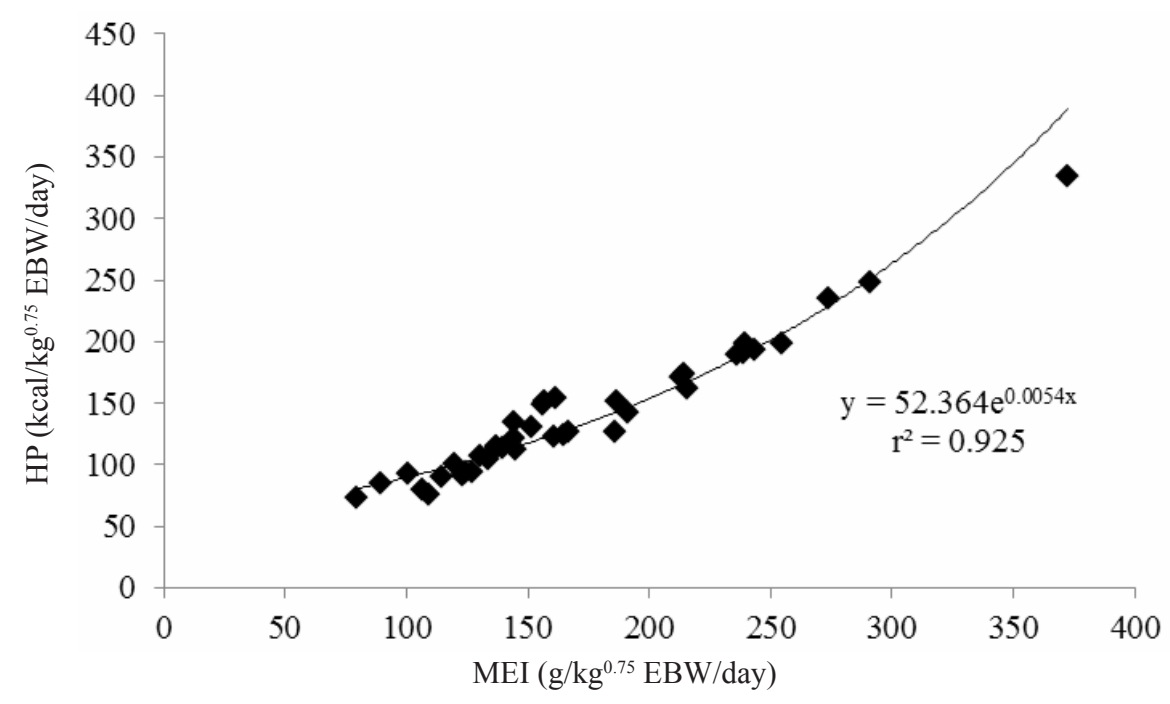

Source: Elaboration of the authors.

Table 3. Gross energy (GE), total digestible nutrients (TDN), dry matter intake for maintenance (DMIm) and gain (DMIg), concentrations of net energy for maintenance (NEm) and gain (NEg) of the diet, metabolizability (qm) and efficiency of metabolizable energy use for maintenance $(\mathrm{km})$ and gain $(\mathrm{kg})$.

\begin{tabular}{lccccc}
\hline & \multicolumn{5}{c}{ Levels of ME (Mcal/kg DM) } \\
\cline { 2 - 5 } Variable & 0.96 & 1.28 & 1.72 & 2.18 & 2.62 \\
\hline GE (Mcal/kg DM) & 4.19 & 4.36 & 4.32 & 4.31 & 4.34 \\
TDN (\%) & 28.01 & 34.46 & 45.39 & 59.39 & 72.36 \\
DMIm $\left(\mathrm{g} / \mathrm{kg}^{0.75} \mathrm{EBW}\right)$ & 84.38 & 63.28 & 47.09 & 37.16 & 30.92 \\
DMIg (g/kg.75 EBW) & 30.48 & 13.40 & 12.47 & 38.75 & 37.99 \\
NEm (Mcal/kg DM) & 0.62 & 0.83 & 1.11 & 1.41 & 1.69 \\
NEg (Mcal/kg DM) & 0.23 & 0.77 & 1.20 & 1.08 & 1.28 \\
$\mathrm{qm}^{1}$ & 0.44 & 0.25 & 0.29 & 0.30 & 0.36 \\
$\mathrm{~km}^{2}$ & 0.64 & 0.64 & 0.64 & 0.64 & 0.64 \\
$\mathrm{~kg}^{2}$ & 0.24 & 0.60 & 0.70 & 0.50 & 0.49 \\
$\mathrm{~kg}^{3}$ & 0.18 & 0.24 & 0.32 & 0.40 & 0.48 \\
$\mathrm{~km}^{3}$ & 0.58 & 0.61 & 0.64 & 0.68 & 0.71 \\
\hline
\end{tabular}

1 - Dietary metabolizability.

2 - Calculated according to Harris (1970).

3 - Calculated according to AFRC (1993).

Source: Elaboration of the authors.

Employing the methodology proposed by Harris (1970), a km value of 0.646 was observed when the relationship NEm/MEm was used, where MEm was determined by the interactive method (52.36/81.00 $=0.646$ ). This value was similar to the one provided by the SRNS, which was 0.644 .
By using the AFRC equation (1993), which suggests a variable $\mathrm{km}$ and is estimated from the metabolizability (qm) of the diet, values from 0.61 to 0.71 (Table 3) were observed for diets with ME concentrations of 1.28 to $2.62 \mathrm{Mcal} / \mathrm{kg} \mathrm{DM}$, respectively. 
These results confirm the values described by Gonzaga Neto et al. (2005), who also reported an increase of 0.66 to $0.68 \mathrm{~km}$ as the concentrate was increased in the Morada Nova lamb diet. Regadas Filho et al. (2011) and Oliveira et al. (2014) observed an increase from 0.68 to $0.73 \mathrm{~km}$ and 0.59 to 0.71 $\mathrm{km}$, respectively, as the energy was incremented in the Santa Ines sheep diet. The metabolizable energy efficiency for weight gain was directly related to gain composition (GARRETT, 1980).

Protein deposition is energetically less efficient than fat synthesis because the synthesis and degradation (turnover) of body protein reduces the energy efficiency of its accumulation (GARRETT, 1980; GEAY, 1984; OWENS et al., 1995). However, fat deposition at high levels, as observed in early animals, may reduce the overall efficiency of utilization of metabolizable energy for weight gain due to the high energy required to maintain the same body mass as in late animals (REGADAS FILHO et al., 2011). High fat deposition is a biological need for animals adapted to regions with seasonality, as this necessitates the storage of fat as an energy reserve source, which may explain the reduced efficiency of utilization of metabolizable energy for weight gain.

Based on the DMI values (Table 3) in relation to the metabolic BW $\left(\mathrm{kg}^{0.75} \mathrm{BW}\right)$ and average daily weight gain (ADG) obtained from the 40 animals, a multiple linear regression equation was determined (Table 4). The average daily gain presented a significant quadratic effect, indicating that the ADG affected the maximum dry matter intake. Thus, the following adjusted equation was generated: $178.365+0.215 \mathrm{ADG}+0.0088 \mathrm{ADG}^{2}+40.172 \mathrm{~kg}^{0.75}$ $\mathrm{BW}(\mathrm{RMSE}=1.419, \mathrm{SEM}=0.573)$. By simulating the DMI for a $20 \mathrm{~kg}$ animal with an ADG of 150 $\mathrm{g}$ and by using the equation developed by Cannas et al. (2004) described in the CNCPS-S, a DMI of $773.42 \mathrm{~g} /$ day was obtained. Using these BW and ADG values in the equation generated in this work, the estimated DMI was $788.54 \mathrm{~g}$ /day, a value only $1.9 \%$ higher than the one predicted by the CNCPS-S. Using the equation generated by Regadas Filho et al. (2011) for Santa Ines lambs, the predicted DMI value was $819.29 \mathrm{~g} /$ day, $3.9 \%$ higher than the one predicted for Morada Nova lambs. Employing these BW and ADG values in the equation developed by Cabral et al. (2008), the predicted value was 810 $\mathrm{g} /$ day, $2.65 \%$ higher than the one predicted in this work. For a $30 \mathrm{~kg}$ animal with an ADG of $250 \mathrm{~g}$, the DMI estimated by our equation was $1.297 \mathrm{~g} / \mathrm{day}$, $10.4 \%$ higher than the one predicted by the equation of the CNCPS-S (1.162 g/day), 6.4\% higher than that estimated by the equation of Regadas Filho et al. (2011) and 17.5\% higher than the value determined by the equation of Cabral et al. (2008), which was $1.070 \mathrm{~g} /$ day.

Table 4. Overall model of multiple equation of dry matter intake in function of the average daily gain and the metabolic body weight.

\begin{tabular}{lcccccc}
\hline Variable & $\begin{array}{c}\text { Parameters of the } \\
\text { equation }\end{array}$ & $\mathrm{SE}$ & $\mathrm{P} \leq$ & $\mathrm{CI}_{95 \%}$ & Adjusted $\mathrm{r}^{2}$ & $\mathrm{VC}$ \\
\hline Intercept & 178.365 & 53.64 & 0.0254 & 56.731 & 0.847 & 25.23 \\
Average daily gain & 0.215 & 0.24 & 0.0093 & 0.4296 & - & - \\
Average daily gain & 0.0088 & 0.01 & 0.0046 & 0.0177 & - & - \\
Metabolic body weight & 40.172 & 5.997 & 0.0027 & 8.0343 & - & - \\
\hline
\end{tabular}

$\mathrm{SE}=$ Standard error; $\mathrm{P} \leq=$ Probability; $\mathrm{CI}_{95 \%}=$ Confidence interval; Adjusted $\mathrm{r}^{2}=$ Adjusted coefficient of determination; $\mathrm{VC}=$ Coefficient of variation.

Source: Elaboration of the authors. 
Total digestible nutrients requirements in $\mathrm{kg} /$ day increased according to the animal's body weight (Table 5). The NRC (2007) reported a TDN requirement of $0.39 \mathrm{~kg}$ /day for weighing $20 \mathrm{~kg}$ of late maturation and a gain of $200 \mathrm{~g}$ per day. This value is close to the one identified in this work $(0.38$ $\mathrm{kg}$ /day). The NRC (2007) recommends $0.66 \mathrm{~kg} /$ day for animals with early growth, which is above the value identified in this work. Based on these results, we conclude that Morada Nova animals can be regarded as late-growth animals, which was also suggested in studies performed by Souza et al. (2011), in which the authors considered the Morada Nova breed as a late breed in comparison to the Santa Ines breed.

Protein requirement values expressed in net protein for maintenance and gain (NPm and NPg), metabolizable protein for maintenance and gain (MPm and MPg), rumen degradable protein (RDP), rumen undegradable protein (RUDP) and crude protein are presented in Table 6.

Regarding the total requirement of metabolizable protein $(\mathrm{MPt})$ for an animal with $20 \mathrm{~kg}$ of BW and an ADG of $200 \mathrm{~g} /$ day, the NRC (2007) suggests 71 g/day of MPt for this animal category. Silva et al. (2010) estimated a MPt requirement of $60.271 \mathrm{~g} /$ day, and Regadas Filho et al. (2011) presented a value of $52.64 \mathrm{~g} /$ day for this animal category.
By converting the MPt requirement into crude protein for this same animal category, a value of $107.87 \mathrm{~g}$ /day was obtained in this work, which was similar to the one described by the NRC (2007), which recommends a supply of $106 \mathrm{~g} /$ day, considering $60 \%$ of rumen undegradable protein for late maturity animals. The rumen degradable protein (RDP) requirements were below those reported by Regadas Filho et al. (2011) for Santa Ines sheep. The microbial protein synthesis produced in the rumen is dependent on the ruminal energy and nitrogen availability (BACH; CALSAMIGLIA; STERN, 2005). According to Paulino (2006), when protein synthesis is maximized, its contribution to meeting the total protein requirements, either metabolizable or crude protein, increases and thus yields nutritional benefits, such as generating excellent quality microbial protein, and economic benefits as they can be synthetized from cheaper nitrogen dietary sources.

Based on the DMI values observed and predicted by the SRNS model, a regression equation was obtained (Figure 2). Because Pearson's correlation coefficient (R) was 0.86 , which indicated that the SRNS model was highly correlated and accurate, the null hypothesis was not rejected $(\mathrm{P}=0.27)$, and thus, the evaluated model was adequately sensitive for predicting the DMI of Morada Nova lambs. 
Table 5. Nutritional requirements of energy for Morada Nova lambs.

\begin{tabular}{|c|c|c|c|c|c|c|c|c|c|c|c|c|}
\hline $\begin{array}{l}\text { Body } \\
\text { weight } \\
(\mathrm{kg})\end{array}$ & $\begin{array}{l}\text { Gain } \\
\text { (g/day) }\end{array}$ & $\begin{array}{c}\text { EBW } \\
(\mathrm{kg})\end{array}$ & $\begin{array}{c}\text { DMI } \\
\text { (g/day) }\end{array}$ & NEm & $\mathrm{NEg}$ & NEt & $\mathrm{MEm}^{1}$ & $\mathrm{MEg}^{2}$ & MEt & $\mathrm{DE}^{3}$ & $\mathrm{TDN}^{4}$ & $\% \mathrm{TDN}$ \\
\hline \multirow{4}{*}{15} & 100 & 10.74 & 594.34 & 0.31 & 0.17 & 0.48 & 0.49 & 0.34 & 0.83 & 1.01 & 0.23 & 38.41 \\
\hline & 150 & 10.74 & 715.46 & 0.31 & 0.25 & 0.56 & 0.49 & 0.50 & 0.99 & 1.20 & 0.27 & 38.10 \\
\hline & 200 & 10.74 & 880.74 & 0.31 & 0.34 & 0.65 & 0.49 & 0.68 & 1.17 & 1.42 & 0.32 & 36.60 \\
\hline & 250 & 10.74 & 1090.16 & 0.31 & 0.42 & 0.73 & 0.49 & 0.84 & 1.33 & 1.62 & 0.37 & 33.63 \\
\hline \multirow{4}{*}{20} & 100 & 15.20 & 668.07 & 0.40 & 0.19 & 0.59 & 0.63 & 0.38 & 1.01 & 1.23 & 0.28 & 41.81 \\
\hline & 150 & 15.20 & 789.19 & 0.40 & 0.28 & 0.68 & 0.63 & 0.56 & 1.19 & 1.45 & 0.33 & 41.70 \\
\hline & 200 & 15.20 & 954.47 & 0.40 & 0.38 & 0.78 & 0.63 & 0.76 & 1.39 & 1.69 & 0.38 & 40.28 \\
\hline & 250 & 15.20 & 1163.90 & 0.40 & 0.47 & 0.87 & 0.63 & 0.94 & 1.57 & 1.91 & 0.43 & 37.31 \\
\hline \multirow{4}{*}{25} & 100 & 19.67 & 737.28 & 0.49 & 0.20 & 0.69 & 0.76 & 0.40 & 1.16 & 1.42 & 0.32 & 43.67 \\
\hline & 150 & 19.67 & 858.41 & 0.49 & 0.31 & 0.80 & 0.76 & 0.62 & 1.38 & 1.69 & 0.38 & 44.60 \\
\hline & 200 & 19.67 & 1023.68 & 0.49 & 0.41 & 0.90 & 0.76 & 0.82 & 1.58 & 1.93 & 0.44 & 42.80 \\
\hline & 250 & 19.67 & 1233.11 & 0.49 & 0.51 & 1.00 & 0.76 & 1.02 & 1.78 & 2.18 & 0.49 & 40.02 \\
\hline \multirow{4}{*}{30} & 100 & 24.13 & 803.10 & 0.57 & 0.22 & 0.79 & 0.89 & 0.44 & 1.33 & 1.62 & 0.37 & 45.83 \\
\hline & 150 & 24.13 & 924.22 & 0.57 & 0.33 & 0.90 & 0.89 & 0.66 & 1.55 & 1.89 & 0.43 & 46.41 \\
\hline & 200 & 24.13 & 1089.49 & 0.57 & 0.43 & 1.00 & 0.89 & 0.86 & 1.75 & 2.13 & 0.48 & 44.44 \\
\hline & 250 & 24.13 & 1298.92 & 0.57 & 0.54 & 1.11 & 0.89 & 1.08 & 1.97 & 2.40 & 0.55 & 41.96 \\
\hline
\end{tabular}

$\mathrm{EBW}=2,645+0,8924 * \mathrm{BW} ; \mathrm{NEm}=$ Net energy maintenance; $\mathrm{NEg}=$ Net energy gain; $\mathrm{NEt}=\mathrm{Net}$ energy total; MEm = Metabolizable energy maintenance; $\mathrm{MEg}=$ Metabolizable energy gain; MEt $=$ Metabolizable energy total; DE $=$ Digestible energy; $\mathrm{TDN}=\mathrm{Total}$ digestible nutrientes.

${ }^{1} \mathrm{~km}=0.64 ;{ }^{2} \mathrm{~kg}=0.51 ;{ }^{3} \mathrm{DE}=\mathrm{MEt} / 0.82 ;{ }^{4} \mathrm{TDN}(\mathrm{kg} / \mathrm{day})=\mathrm{DE} / 4.409(\mathrm{NRC}, 2007)$.

Source: Elaboration of the authors.

Table 6. Nutritional requirements of protein for Morada Nova lambs.

\begin{tabular}{rcccccccccccc}
\hline $\begin{array}{c}\text { Body } \\
\text { weight } \\
(\mathrm{kg})\end{array}$ & $\begin{array}{c}\text { Gain } \\
\text { (g/day) }\end{array}$ & $\mathrm{NPm}^{1}$ & $\mathrm{NPg}$ & $\mathrm{NPt}$ & $\mathrm{MPm}^{2}$ & $\mathrm{MPg}^{3}$ & $\mathrm{MPt}$ & $\mathrm{MicP}(\mathrm{g})$ & $\mathrm{RDP}^{4}$ & $\mathrm{RUP}^{5}$ & $\mathrm{CP}^{3}(\mathrm{~g})$ & $\mathrm{CP}^{\%}$ \\
\hline \multirow{4}{*}{15} & 100 & 13,95 & 13,89 & 27,84 & 13,95 & 27,79 & 41,74 & 27,40 & 30,41 & 30,25 & 60,66 & 10,21 \\
& 150 & 13,95 & 20,84 & 34,79 & 13,95 & 41,68 & 55,63 & 32,71 & 36,30 & 43,37 & 79,67 & 11,14 \\
& 200 & 13,95 & 27,79 & 41,74 & 13,95 & 55,57 & 69,52 & 38,68 & 42,94 & 55,96 & 98,89 & 11,23 \\
& 250 & 13,95 & 34,73 & 48,68 & 13,95 & 69,47 & 83,42 & 43,99 & 48,83 & 69,08 & 117,91 & 10,82 \\
\hline \multirow{4}{*}{20} & 100 & 17,31 & 14,39 & 31,69 & 17,31 & 28,78 & 46,08 & 33,52 & 37,21 & 30,79 & 67,99 & 10,18 \\
& 150 & 17,31 & 21,58 & 38,89 & 17,31 & 43,16 & 60,47 & 39,49 & 43,84 & 43,99 & 87,83 & 11,13 \\
& 200 & 17,31 & 28,78 & 46,08 & 17,31 & 57,55 & 74,86 & 46,13 & 51,21 & 56,67 & 107,87 & 11,30 \\
& 250 & 17,31 & 35,97 & 53,28 & 17,31 & 71,94 & 89,25 & 52,11 & 57,84 & 69,87 & 127,71 & 10,97 \\
\hline \multirow{4}{*}{25} & 100 & 20,46 & 14,77 & 35,23 & 20,46 & 29,53 & 49,99 & 38,63 & 42,88 & 31,58 & 74,47 & 10,10 \\
& 150 & 20,46 & 22,15 & 42,61 & 20,46 & 44,30 & 64,76 & 45,94 & 50,99 & 44,20 & 95,19 & 11,09 \\
& 200 & 20,46 & 29,53 & 49,99 & 20,46 & 59,06 & 79,52 & 52,58 & 58,36 & 57,34 & 115,70 & 11,30 \\
& 250 & 20,46 & 36,91 & 57,37 & 20,46 & 73,83 & 94,29 & 59,21 & 65,73 & 70,49 & 136,22 & 11,05 \\
\hline & 100 & 23,46 & 15,07 & 38,53 & 23,46 & 30,14 & 53,60 & 44,17 & 49,02 & 31,67 & 80,70 & 10,05 \\
30 & 150 & 23,46 & 22,61 & 46,07 & 23,46 & 45,22 & 68,68 & 51,47 & 57,13 & 44,67 & 101,80 & 11,01 \\
& 200 & 23,46 & 30,14 & 53,60 & 23,46 & 60,29 & 83,75 & 58,11 & 64,50 & 58,20 & 122,70 & 11,26 \\
& 250 & 23,46 & 37,68 & 61,14 & 23,46 & 75,36 & 98,82 & 65,41 & 72,60 & 71,20 & 143,80 & 11,07 \\
\hline
\end{tabular}

$\mathrm{NPm}=$ Net protein maintenance; $\mathrm{NPg}=$ Net protein gain $; \mathrm{NPt}=$ Net protein total; $\mathrm{MPm}=$ Metabolizable protein maintenance; $\mathrm{MPg}$ = Metabolizable protein gain; $\mathrm{MPt}=$ Metabolizable protein total; MicP = Microbial protein; $\mathrm{RDP}=\mathrm{Rumen}$ degradable protein; RUP $=$ Rumen undegradable protein, $\mathrm{CP}=$ Crude protein.

${ }^{1} \mathrm{NPm}=1.73 \mathrm{~g} \mathrm{CP} / \mathrm{kg}^{0.75} \mathrm{BW} / \mathrm{day} ;{ }^{2} \mathrm{kpm}=1.00 ;{ }^{3} \mathrm{kpg}=0.59 ;{ }^{4} \mathrm{RDP}=1.11 *(120 * \mathrm{TDN}) ;{ }^{5} \mathrm{RUP}=[(\mathrm{MPt}-(120 * \mathrm{TDN} * 0.64)] / 0.80$ (Marcondes et al., 2010).

Source: Elaboration of the authors. 
Figure 2. Relationship between the values of dry matter intake (DMI) observed and those predicted by the SRNS model in Morada Nova lambs.

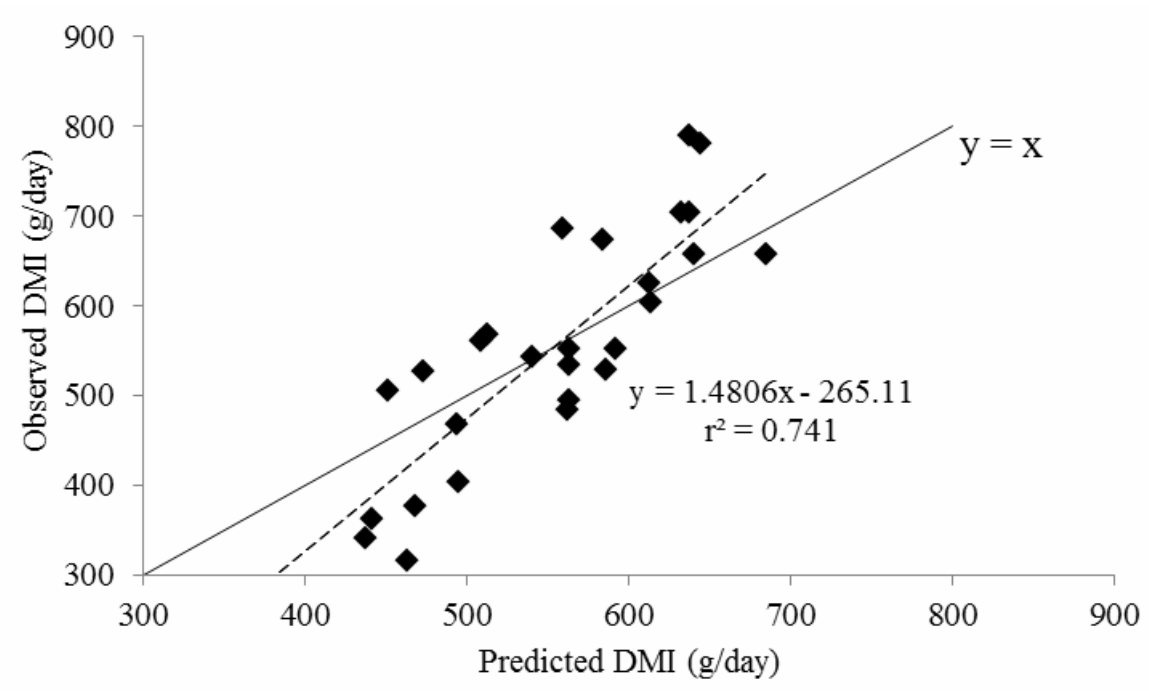

Source: Elaboration of the authors.

The dry matter intake exhibits the greatest impact on the response of the animal (POPPI, 2008). Application of mechanistic models to predict the DMI is a feasible alternative in ruminant nutrition studies. Because they work to elucidate the mechanisms controlling changes in ingestion rates, the application of mathematical models to simulate animal responses enriches those models, thus improving their precision and accuracy.

Regarding the average daily gain, the SRNS model was highly correlated, $\mathrm{R}=0.880(\mathrm{P}<0.001)$, and the null hypothesis was not rejected $(\mathrm{P}=$ 0.246). The equation adjusted for the observed and predicted ADG is presented in Figure 3, where the RMSE was equal to 1.545 .

Figure 3. Relationship between the daily average gain (ADG) observed and that predicted by the SRNS model in Morada Nova lambs.

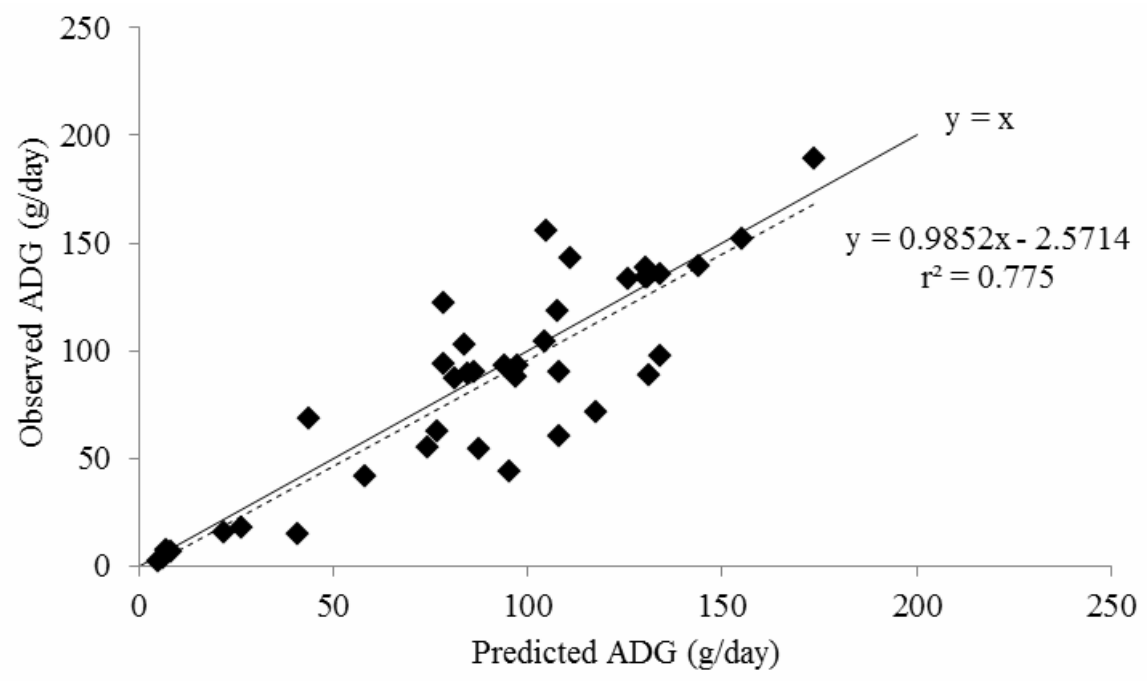

Source: Elaboration of the authors. 
Regadas Filho et al. (2011) reported that the SRNS model overestimated the ADG by $5.18 \%$ for Santa Ines lambs. Oliveira et al. (2014) observed that the SNRS model underestimated the average daily gain by $24,6 \%$ for the same racial group. The authors attributed this to a lower efficiency of utilization of metabolizable energy for the weight gain observed in diets with lower amounts of metabolizable energy. Galvani et al. (2008) reported that differences between the ADG predicted by the SRNS model may also be explained by variations in the nutritional requirements of the animals. Few studies have evaluated models such as the SRNS in woolless sheep reared in Brazilian conditions, unlike the bovine species, for which the published models have been extensively evaluated. From larger databases, sheep models developed under different Brazilian conditions must be more accurately and precisely evaluated.

\section{Conclusions}

The efficiency of utilization of metabolizable energy for maintenance and weight gain in Morada Nova lambs agrees with the values presented by the principal feeding system and the nutritional requirements of small ruminants.

The SRNS model is reliable for predicting the dry matter intake and daily weight gain in Morada Nova lambs.

We conclude that further studies should be conducted to be able to compile various results to verify the accuracy of using the SRNS model for prediction of dry matter intake and weight gain in animals raised in the tropics.

\section{Acknowledgments}

The authors would like to thank the Conselho Nacional de Desenvolvimento Científico e Tecnológico (CNPq) and the Banco do Nordeste do Brasil for financial support and to acknowledge the contribution of the two anonymous reviewers and the editor for improving the quality of the manuscript.

\section{References}

AGRICULTURAL AND FOOD RESEARCH COUNCIL - AFRC. Energy and protein requirements of ruminants. Wallingford: Commonwealth Agricultural Bureaux International, 1993. $159 \mathrm{p}$.

ASSOCIATION OF OFFICIAL ANALYTICAL CHEMISTRY - AOAC. Official methods of analysis. $15^{\text {td }}$ ed. Virginia: Arlington, 1990. 1298 p.

BACH, A.; CALSAMIGLIA, S.; STERN, M. D. Nitrogen metabolism in the rumen. Journal of Dairy Science, Champaign, v. 8, p. 9-21, 2005. Supplement E.

CABRAL, L. S.; NEVES, E. M. O.; ZERVOUDAKIS, J. T.; ABREU, G.; RODRIGUES, R. G.; SOUZA, A. L.; OLIVEIRA, I. S. Estimativas dos requisitos nutricionais de ovinos em condições brasileiras. Revista Brasileira de Saúde e Produção Animal, Salvador, v. 9, n. 3, p. 529542, 2008.

CANNAS, A.; ATZORI, A. S.; BOE, F.; TEIXEIRA, I. A. M. A. Energy and protein requirements of goats. In: CANNAS, A.; PULINA, G. (Ed.). Dairy goat, feeding and nutrition. Wallingford: Commonwealth Agricultural Bureaux International, Cambridge, 2007. p. 118-146.

CANNAS, A.; TEDESCHI, L. O.; FOX, D. G.; PELL, A. N.; VAN SOEST, P. J. A mechanistic model for predicting the nutrient requirements and feed biological values for sheep. Journal of Animal Science, Champaign, v. 82, n. 1, p. 149-169, 2004.

CAPPELLE, E. R.; VALADARES FILHO, S. C.; SILVA, J.F.C.; CECON, P. R. Estimativas do valor energético a partir de características químicas e bromatológicas dos alimentos. Revista Brasileira de Zootecnia, Viçosa, v. 30, n. 6, p. 1837-1856, 2001.

CASALI, A. O.; DETMANN, E.; VALADARES FILHO, S. C.; PEREIRA, J. C.; HENRIQUES, L. T.; FREITAS, S. G.; PAULINO, M. F. Influência do tempo de incubação e do tamanho de partículas sobre os teores de compostos indigestíveis em alimentos e fezes bovinas obtidos por procedimentos in situ, Revista Brasileira de Zootecnia, Viçosa, v. 37, n. 2, p. 335-342, 2008.

COSTA, M. R. G. F.; PEREIRA, E. S.; SILVA, A. M. A.; PAULINO, P. V. R.; MIZUBUTI, I. Y.; PIMENTEL, P. G.; PINTO, A. P.; ROCHA JUNIOR, J. N. Body composition and net energy and protein requirements of Morada Nova lambs. Small Ruminant Research, Amsterdam, v. 114, n. 2, p. 206-213, 2013. 
COMMONWEALTH SCIENTIFIC AND INDUSTRIAL RESEARCH ORGANIZATION - CSIRO. Feeding standards for Australian livestock - ruminants. Victoria: Australia Agricultural Council, 1990. 266 p.

FOX, D. G.; TEDESCHI, L. O.; TYLUTKI, T. P.; RUSSEL, J. B.; VAN AMBURGH, M. E.; CHASE, L. E.; PELL, L. E.; OVERTON, T. R. The Cornell net carbohydrate and protein system model for evaluating herd nutrition and nutrient excretion. Animal Feed Science and Technology, Amsterdam, v. 112, n. 1-4, p. 29-78, 2004.

GALVANI, D. B.; PIRES, C. C.; KOZLOSKI, G. V.; WOMMER, T. P. Energy requirements of texel crossbred lambs. Journal of Animal Science, Champaign, v. 86, n. 12, p. 3480-3490, 2008.

GARRETT, W. N. Factors influencing energetic efficiency of beef production. Journal of Animal Science, Champaign, v. 51, n. 6, p. 1434-1440, 1980.

GEAY, Y. Energy and protein utilization in growing cattle. Journal of Animal Science, Champaign, v. 58, n. 3, p. 766-778, 1984.

GONZAGA NETO, S.; SILVA SOBRINHO, A. G.; RESENDE, K. T.; ZEOLA, N. M. B.; SILVA, A. M. A.; ROMBOLA, L. G. Composição corporal e exigências nutricionais de proteína e energia para cordeiros Morada Nova. Revista Brasileira de Zootecnia, Viçosa, v. 34, n. 6, p. 2446-2456, 2005. Suplemento.

HALL, M. B. Calculation of non-structural carbohydrate content of feeds that contain non-protein nitrogen. Gainesville: University of Florida, 2000. p. A25-A34. (Bulletin, n. 339).

HARRIS, L. F. Nutrition research techniques for domestics and wild animals. Utah: Logan, 1970. 240 p. v. 1.

INSTITUT NATIONAL DE LA RECHERCHE AGRONOMIQUE - INRA. Alimentation des ruminants, Versailles: INRA Publications, 1978. 697 p.

KOHN, R. A.; KALSCHEUR, K. F.; HANIGAN, M. Evaluation of models for balancing the protein requirements of dairy cows. Journal of Dairy Science, Champaign, v. 81, n. 12, p. 3402-3414, 1998.

LICITRA, G.; HERNANDES, T. M.; VAN SOEST, P. J. Standardization of procedures for nitrogen fractionation of ruminants feeds. Animal Feed Science and Technology, California, v. 57, n. 4, p. 347-358, 1996.

LOFGREEN, G. P.; GARRETT, W. N. A system for expressing net energy requirements and feed values for growing and finishing beef cattle. Journal of Animal Science, Champaign, v. 27, n. 3, p. 793-806, 1968.
MARCONDES, M. I.; GIONBELLI, M. P.; VALADARES FILHO, S. C.; CHIZZOTTI, M. L.; PAULINO, M. F. Exigências nutricionais de proteína para bovinos de corte. In: VALADARES FILHO, S. C.; MARCONDES, M. I.; CHIZZOTTI, M. L. (Ed.). Exigências nutricionais de zebuinos puros e cruzados: BR-corte. 2. ed. Viçosa: Universidade Federal de Viçosa, 2010. p. 113-133.

McDONALD, P.; ORSKOV, E. R. The estimation of protein degradability in the incubation measurements weighted according to rate of passage. Journal of Agricultural Science, Cambridge, v. 92, n. 2, p. 499-503, 1979.

MERTENS, D. R. Gravimetric determination of amylase treated neutral detergent fiber in feeds with refluxing in beaker or crucibles: collaborative study. Journal of AOAC International, Gaithersburg, v. 85, n. 6, p. 1217 1240, 2002.

MITCHELL, P. L.; SHEELY, J. E. Comparison of predictions and observations to assess model performance: a method of empirical validation. In: KROPFF, M. J.; TENG, P. S.; PAGGARWAL, K.; BOUMA, J.; BOUMAN, B. A. M.; JONES, J. W.; VAN LAAR, H. H. (Ed.). Applications of systems approaches at the field level. Boston: Kluwer Academic, 1997. p. 437-451.

NATIONAL RESEARCH COUNCIL - NRC. Nutrient requirements of beef cattle. $6^{\text {th }}$ ed. Washington, D. C.: National Academy Press, 1996. 244 p.

Nutrient requirements of beef cattle. $7^{\text {th }}$ ed. Washington, D. C.: National Academy Press, 2000. 242 p.

Nutrient requirements of small ruminants: sheep, goats, cervids and new world camelids. $6^{\text {th }}$ ed. Washington, D. C.: National Academy Press, 2007. 384 p.

OLIVEIRA, A. P.; PEREIRA, E. S.; PINTO, A. P.; SILVA, A. M. A.; CARNEIRO, M. S. S.; MIZUBUTI, I. Y; RIBEIRO, E. L. A.; CAMPOS, A. C. N.; GADELHA, C. R. F. Estimativas dos requisitos nutricionais e utilização do modelo small ruminant nutrition system para ovinos deslanados em condições semiáridas. Semina: Ciências Agrárias, Londrina, v. 35, n. 4, p. 1985-1998, 2014.

OWENS, F. N.; GILL, D. R.; SECRIST, D. S.; COLEMAN, S. W. Review of some aspects of growth and development of feedlot cattle. Journal of Animal Science, Champaign, v. 73, n. 10, p. 3152-3172, 1995.

PAULINO, P. V. R. Desempenho, composição corporal e exigências nutricionais de bovinos nelore de diferentes classes sexuais. 2006. Tese (Doutorado em Zootecnia) Universidade Federal de Viçosa, Viçosa. 
POPPI, D. P. The dilemma in models of intake regulation: Mechanistic or empirical. In: FRANCE, J.; KEBREAB, E. (Ed.). Mathematical modeling in animal nutrition. Wallingford: CAB International, 2008. p. 121-141.

REGADAS FILHO, J. G. L.; PEREIRA, E. S.; VILLARROEL, A. B. S.; PIMENTEL, P. G.; FONTENELE, R. M.; COSTA, M. R. G. F.; MAIA, I. S. G.; SOMBRA, W. A. Efficiency of metabolizable energy utilization for maintenance and gain and evaluation of small ruminant nutrition system model in Santa Ines sheep. Revista Brasileira de Zootecnia, Viçosa, v. 40, n. 11, p. 2558-2564, 2011.

STATISTICAL ANALYSIS SYSTEM - SAS. System for windows. Release 9.1 (TS1M3). Cary: SAS Institute, 2003. 78 p.

SNIFFEN, C. J.; O’CONNOR, D. J.; VAN SOEST, P. J.; FOX, D. G.; RUSSELL, J. B. A net carbohydrate and protein system for evaluating cattle diets: carbohydrate and protein availability. Journal of Animal Science, Champaign, v. 70, n. 11, p. 3562-3577, 1992.

SOUZA, L. A.; CARNEIRO, P. L. S.; MALHADO, C. H. M.; PAIVA, S. R.; CAIRES, D. N.; BARRETO, D. L. F. Curvas de crescimento em ovinos da raça morada nova criados no estado da Bahia. Revista Brasileira de Zootecnia, Viçosa, v. 40, n. 8, p. 1700-1705, 2011.
TEDESCHI, L. O.; FOX, D. G.; RUSSEL, J. B. Accounting for the effects of a ruminal nitrogen deficiency within the structure of the Cornell Net Carbohydrate and Protein System. Journal of Animal Science, Champaign, v. 78, n. 6, p. 1648-1658, 2000.

VALADARES FILHO, S. C. Digestão total e parcial da matéria seca e carboidratos em bovinos e bubalinos. 1985. Tese (Doutorado em Zootecnia) - Universidade Federal de Viçosa, Viçosa.

VAN SOEST, P. J.; ROBERTSON, J. B. Analysis of forages and fibrous foods. AS 613 Manual, Department of Animal Science. Ithaca: Cornell University. 1985.

VAN SOEST, P. J.; ROBERTSON, J. B.; LEWIS, B. A. Methods for dietary fiber, neutral-detergent fiber and nonstarch polysaccharides in relation to animal nutrition. Journal of Dairy Science, Champaign, v. 74, n. 10, p. 3583-3597, 1991.

WEISS, W. P. Energy prediction equations for ruminant feeds. In: CORNELL NUTRITION CONFERENCE FOR FEED MANUFACTURERS, 61., 1999, Ithaca. Proceedings... Ithaca: Cornell University, 1999. p. 176185. 
